\title{
Textual Evolution
}

\section{The Translation of Louis Figuier's La Terre avant le déluge}

\author{
RICHARD SOMERSET \\ Nancy-Université, France
}

\begin{abstract}
In 1863, the French popularizer of science Louis Figuier produced a work that would become a classic of popular science and open up the new field of palaeontology to a wide audience of non-specialists. Its success derived largely from the author's capacity to deploy copious empirical information within an engaging and suggestive narrative framework. This narrative had strong ideological implications, its characteristic pattern of global progression broken by local discontinuities being compatible only with a scheme in which the course of nature was guided by providential design. However, the contemporary English translations of the work did not reproduce this outlook. While Figuier's work remained an effective tool for the popularization of the discipline, the relationship between empirical fact and divine intervention was subtly changed in translation, the English version being more pious and less hostile to evolution than the French original. This paper presents an account of how Figuier's translators achieved this shift in ideological orientation and explores their possible motivations for doing so.
\end{abstract}

Keywords: Louis Figuier; Popular science; Histories of life; Evolution; 19th century

The 'History of Life' was a new genre in the mid-19th century. It popularized the results of palaeontology - itself a young discipline - by translating them into something like story form. It was a Bildungsroman of which Life itself was the hero, tracing the stages of its development from primitive beginnings in the primeval seas to the complex forms of the modern world. The genre was to play a significant role in the elaboration of modern popular science because it enabled a style that imitated fiction, and provided many of the same pleasures. Rather than explain results, the History of Life could tell a gripping story - and claim that it was all true. The narrative approach also allowed the genre to carry its ideological orientations discretely. Popularizers interested in attacking or defending evolutionary theory, notably, could tell a story that suggested a plot dynamic of material emergence or else tell a story of material discontinuity, and thus take position without having to address the theory directly. Instead, they could claim to be doing nothing more than letting the earth itself tell the objective story of Life. For all of these reasons, the genre was to become a powerful discursive tool.

First published in 1863, Louis Figuier's La Terre avant le déluge was arguably the work that set the standards for the emergent History of Life genre. According to Martin Rudwick, it "established the genre of scenes from deep time throughout the western world" (1992:219) and, although this comment was directed specifically at the "ideal scenes" depicting the various geological ages executed by Edouard Riou that illustrated Figuier's text, it could just as well apply to the book as a whole. It was a widely read text throughout the second half of the 19th-century, going through nine editions in Figuier's lifetime, the last edition appearing in 1883. By the author's own estimation, the first two editions sold 18,000 copies in less than a year. ${ }^{1}$ The book was translated into various European languages, including Spanish and

\footnotetext{
${ }^{1}$ Figuier proudly cited his own sales figures in the prefaces of succeeding editions. He later claimed sales of 25,000 copies for the first three editions and 30,000 for the first four.
} 
Danish (ibid.:212). The first English translation was undertaken by a translator who signed himself or herself "WSO" and was published in 1865 as The World Before the Deluge. ${ }^{2}$ The same title was retained for the five further English editions that would appear between 1867 and 1891, this time under the supervision of Henry Bristow and, for the last edition, of Henry Bristow and Robert Brown. ${ }^{3}$ All of these editions were also printed in the United States.

Apart from the general goal of publicizing the findings of the relatively new discipline of palaeontology, Figuier seems to have had two other important agendas in producing La Terre avant le déluge (hereafter $T A D$ ). The more important of them stemmed from the desire to counter evolutionist sympathies in the popular treatments of palaeontology that were beginning to appear at the time. ${ }^{4}$ The 1862 translation of Darwin's Origin of Species by Clémence Royer may also have played a part in prompting a reaction. ${ }^{5}$ Figuier's other agenda was the promotion of a pedagogical stance that made empiricism - as opposed to fantasy - the proper stuff for the education of the youth. This position was directly stated in the preface of $T A D$, where "tales and legends" were denounced as "dangerous" for children: "Ils entretiennent et surexcitent cette inclinaison au merveilleux qui n'est déjà que trop naturelle à l'esprit humain"6 (Figuier 1863a:v). If fantasy were allowed to maintain its sway unchecked over the infantile mind, there would be serious consequences not only for the individual child but for society as a whole: "Ainsi le merveilleux qui s'est emparé d'une âme, à l'heure, trop accessible, de son éveil, ne lâchera plus sa proie. Comment dès lors être surpris des vacillations de l'esprit public ? Comment s'étonner de l'invasion alternative d'un fanatisme ignorant ou d'un socialisme menaçant ?"7 (Figuier 1863a:v).

The two agendas were evidently related, and Figuier's hard-line 'facts-only' pedagogical stance was in large part a reaction to the narrative strategy adopted by Boitard. In Paris avant les hommes, Figuier's rival had chosen to work within the traditions of the fable. He had his hero carried away on a flying stone - an aérolithe - by a friendly limping demon - the diable boiteux - back into the geological past, a territory they explore together, discovering in their peregrinations the different creatures characteristic of each particular age. Many of their encounters involve animals presented as mixtures of types: half-way between fish and reptile, for example, or between monkey and man. The result is that the 'recapitulative' journey of the hero suggests a plot dynamic of gradual emergence for nature's story, with each type gradually shading into the next, thus evidently suggesting an evolutionary pattern. For Figuier, the whimsical style and the whimsical theorizing went hand-in-hand; proper science had no need for such an extravagant narrative framework. For his part, he would tell the story naturalistically, without an intrusive narrator; his was to be the measured voice of reason: "Le style grave et précis du professeur dans ses cours; comme on le disait au dernier siècle, le ton

\footnotetext{
${ }^{2}$ Rudwick (1992:212) identifies "WSO" as W.S. Ormerod, and notes that he was a member of the Geological Society of London. For the sake of simplicity, we will hereafter assume the male gender of WSO.

${ }^{3}$ Brown seems to have made only a few minor changes in the preface of the 1891 translation, so WSO and Bristow can be considered the only important contributors.

${ }^{4}$ The usual reference here is Pierre Boitard's Paris avant les hommes of 1861, a work that has subsequently been largely forgotten and is now hard to find. Rudwick (1992) devotes several pages to the description of Boitard's work, concentrating particularly on its illustrations.

${ }^{5}$ For detailed studies of Royer's translation, see Brisset (2002) and Miles (1989).

6 "The tales and legends that we give as the teachers of infancy are dangerous, because they cultivate and excite that inclination for the marvelous which is already excessive in the human mind" (Figuier, trans. WSO, 1865:4).

7 "In this manner the love of the marvellous pervades the mind in the hour of its awakening, leaving it a prey to the worst superstitions. How, then, should we be astonished at the alternate appearance of fanatical ignorance and threatening socialism ...?" (Figuier, trans. WSO, 1865:4).
} 
de conversation entre honnêtes gens, voilà, selon nous, ce qui convient le mieux aux ouvrages destinés à populariser la science" (Figuier 1863a:x).

Figuier's empirical stance and his anti-fantasy pedagogy were thus primarily actuated by the desire to prevent evolutionary ideas from taking root amongst the French youth, and to undercut the attractiveness of the more fantastic publications that that theory's partisans might deploy. However, he could not hope to compete if he adhered strictly to his own empirical standards, since to do so would be to undermine the book's popular appeal. The compromise came with the illustrations, Riou's "ideal scenes" being included precisely to fill the gap between information and imagination. By taking the empirical high ground, but also including speculative and spectacular visual reconstructions, Figuier tried to have it both ways: this was 'proper science', but proper science that nevertheless came with a thrill. The success of this compromise strategy is evident from the fact that Boitard's more whimsical publication disappeared almost without a trace after the publication of $T A D$, and had no further impact upon the development of the 'History of Life' genre. So Figuier clearly won out in the formal contest of styles, at least in France, but it is less clear that his publication always had the ideological impact he had hoped for, especially when exported into a different cultural and intellectual context. For instance, the English translation by 'WSO', later augmented by Henry Bristow, did not carry exactly the message intended by Figuier, but gave the work a distinctive slant no doubt calculated to render it congenial to the tastes of the Anglo-American reading public. Specifically, The World Before the Deluge (hereafter WBD) was both less strictly empirical in attitude and less anti-evolutionary in implication than the original French text had been. This shift will be the focus of this paper, which will examine how the English translators modified Figuier's text, and why.

\section{Narrative structure as argument}

Despite the anti-fantasy position of the preface, Figuier clearly realized that the success of his project would depend upon his capacity to balance empirical credibility with imaginative appeal. The outline of the project was thus announced in terms that balance sobriety of tone on the one hand with the promise of wonders on the other:

Dans La Terre avant le déluge, nous nous proposons d'exposer les diverses transformations que la terre a subies pour arriver à son état actuel, de décrire sa structure intérieure, et de faire revivre, pour l'instruction de nos jeunes lecteurs, les diverses générations d'animaux et de plantes qui ont habité notre planète avant la création de l'homme et des animaux contemporains. (Figuier 1863a:xi) ${ }^{9}$

This sentence neatly characterizes the History of Life genre in the form it took under Figuier's influence. It is the story of each age, arranged chronologically, and dealt with empirically. The story is not the author's invention, it is the story of Life itself; that is why he says that he

\footnotetext{
${ }^{8}$ This sentence was not translated by the contemporary English translators, probably because it occurred in a passage devoted to Fuguier's intention to publish a whole series of books on the subject of the scientific study of nature. Here is my own rather literal translation: "The grave and serious style of a teacher in his classroom; the tone of conversation between gentlemen; this is, in our opinion, the appropriate register for works whose goal is the poularization of the sciences".

${ }^{9}$ The contemporary English translation takes drastic liberties with this passage. It will be cited in due course; in the meantime, here is my own rather literal translation of this passage: "In The World Before the Deluge, we propose to expose the various transformations which the earth has undergone to arrive at its current state, to describe its internal structure, and for the instruction of our young readers, to bring back to life the various generations of animals and plants which lived on the surface of our planet prior to the creation of man and the modern animals".
} 
is going to "expose" each of its stages. So far, so empirical. But Figuier also says that he is going to "bring back to life" the various animal and plant types of each age. Of course this 'resuscitation' was meant to have a reliable empirical basis, but the more complete the reconstructions tried to be, the more they had to tend towards the speculative. The potential confusion between the two registers was successfully limited by concentrating the speculative content in Riou's visual material, so that the text itself might not appear fanciful. It was Figuier's finesse in striking the right compromise that made $T A D$ simultaneously convincing as science and engaging as narrative.
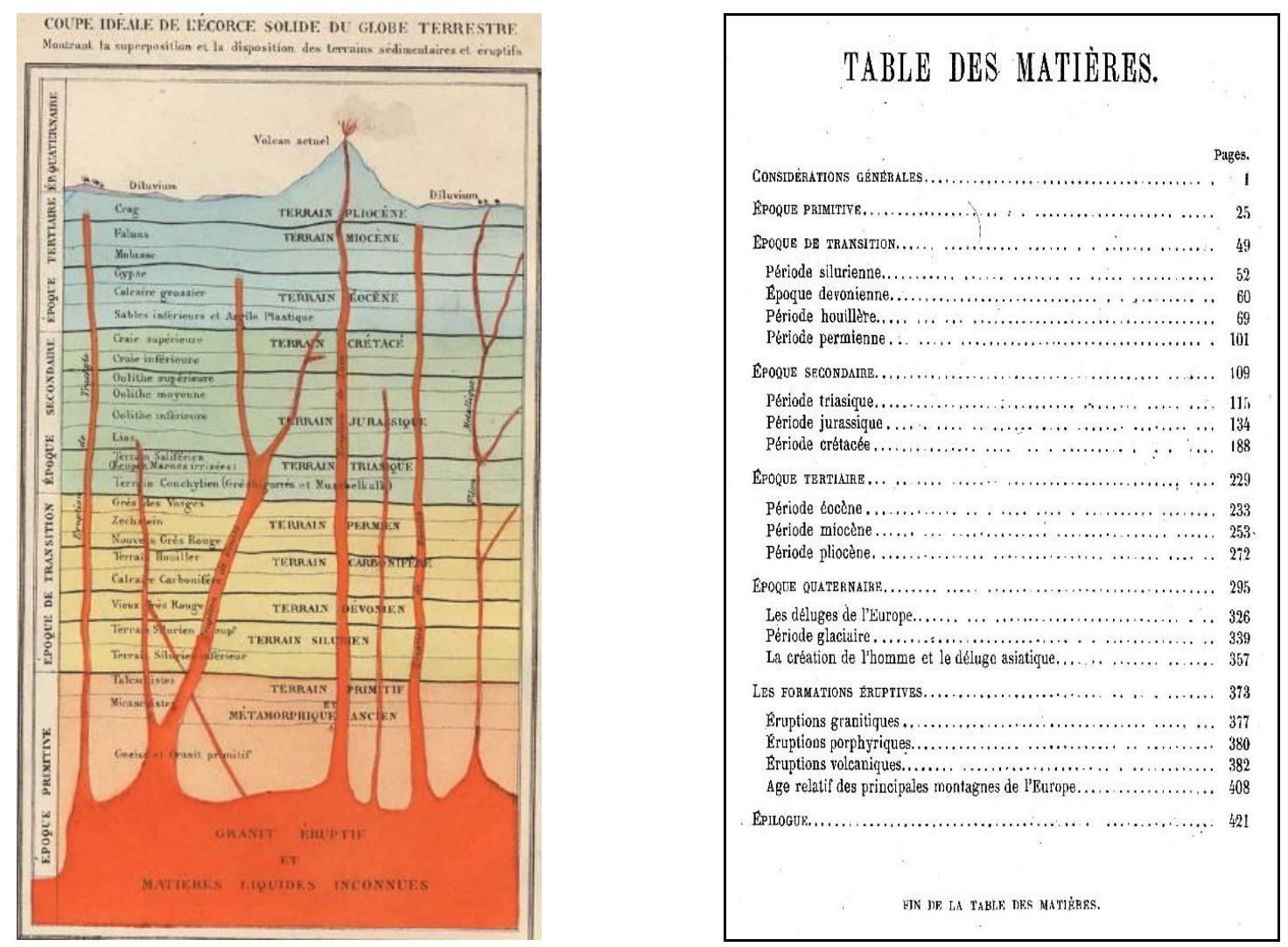

Figure 1. Left: TAD frontispiece, all French editions. Right: TAD table of contents (Figuier $1863 a)$

The structure of TAD echoed Figuier's methodological concerns. The work's frontispiece was not one of Riou's engaging "ideal scenes" but a sober cross section of the earth's crust broken down into a colour-coded sequence of epochs, and each of these in turn broken down into a series of periods. It was an instant lesson in stratigraphy showing that the most recent strata are the most superficial, and that the progression into the depths of the crust is effectively a journey back in geological time, thus providing readers with a sort of chronological route-map to help them follow the stages of the story to come. The table of contents picked up on this stratigraphical sequence, working chronologically from the bottomup, with each successive chapter title reproducing the names of the strata in the frontispiece (Figure 1). In this very tangible way, then, Figuier was able to present $T A D$ as the direct résumé of the story contained in the earth's crust. The reader's route through the geological past had been clearly signposted by this most sober of guides; from the start it was evident that this was going to be a very different sort of journey from that which had been undertaken by Boitard's hero on his aérolithe! 
The material content of each chapter was broadly similar, with the material information being conveyed visually, by means of a large number of specimen diagrams, as well as textually. A typical chapter starts with contextualizing material that serves to remind the reader what stage of the story has been reached. After this reminder of the overarching plot structure, we move on to the empirical detail. This usually starts with a survey of the fossil finds associated with the strata in question. These fossils are then 'reconstructed' to show what the animals or plants themselves probably looked like when alive, and to allow them to be classified in their due taxonomical places. The survey is accompanied by new specimen diagrams, partly speculative this time, and generally presented in reverse order, working down from the 'highest' types to the 'lowest'. There are often a few remarks about the probable nature of the landscape during this period, as deduced from the mineralogical properties of the strata and the forms of life associated with it. And finally, as a closing shot, there will be the "ideal scene" drawn by Riou, which is intended to capture all of this empirical material together in a single 'moment': the landscape, the vegetation, and the animals leading their normal lives.

Figuier's supposedly objective review of the main 'events' in the story of Life's progression is inevitably structured around a certain plot dynamic. In fact, it would be more accurate to say that he gave his story a dual plot structure. The detailed narrative, with its mass of empirical detail, naturalistically relates the story of the material progression of the state of the earth. Overarching this is a wider, more globalizing narrative, largely speculative in origin, interpretative in goal, and mainly carried by Riou's series of "ideal scenes". The material micro-narrative is meant to tell us 'what actually happened' while the more speculative macro-narrative gives a meaningful shape to the whole, and allows us to gain a sense of 'what it all means'.

The general plot dynamic is one of progression, with Life moving in incremental stages from humble origins to the fulfilment of a glorious destiny when it finally takes on human form. Each epoch is associated with a stage on this pathway: the primitive epoch is the age of the invertebrates; the transition epoch corresponds to the age of the fish; the secondary to the reptiles; the tertiary to the mammals; and the quaternary to man. It would be hard to imagine a more reassuringly flattering story than this! Ironically enough, Figuier's rival proponents of evolution would use exactly the same general plot for their own purposes and, to a modern mind at least, a progressive plot does indeed seem more compatible with an evolutionary outlook. So the question in Figuier's case is about the controlling of narrative dynamics; how, in fact, was he able to prevent progression from looking like derivation? The answer lies in the particular interruptive form the French author gave to his micro-narrative of material process. Where the macro-narrative follows a trajectory of smooth progression, the micronarrative is given just the opposite texture: one characterized by breaks and discontinuities. For example, whenever he introduces a new period or especially a new epoch, Figuier does everything he can to stress the difference between the characteristic beings of this epoch as against those of the previous one. They must not be seen as derivative, but as radically new. This is one of the reasons why the author presents the empirical survey of each age in topdown taxonomical order. For example, in the chapter on the Eocene, the first period of the Tertiary epoch, Figuier opens his empirical survey with the pachyderms, a group that is unlikely to suggest any bridges 'back' to the reptiles. An author seeking an evolutionary plot structure would choose a less imposing mammalian form for this part of the story.

Figuier's progressive macro-narrative is a story whose dynamic is assured by the creative will of God, which is why its form can be regular and its tendency directed towards a definite finality. Meanwhile, the material micro-narrative is one that is characterized by discontinuities because material processes must not be permitted to carry any globalizing plot-building potential. By separating the two narrative levels, Figuier was able to achieve the startling 
illusion of global continuity emerging from local discontinuities. He imposed a providential plot on a background of material plotlessness, and thus made the empirical facts tell an antievolutionist story.

\section{The English translations}

As I have already mentioned, TAD was translated into English as The World Before the Deluge in 1865, within two years of publication of the French text. Nevertheless, things had gone so fast for Figuier that this first English translation was based on the fourth French edition, which had appeared in 1864. The first translator remained anonymous, only signing himself WSO; subsequent English editions were augmentations by Henry Bristow of this initial version. Bristow was a workaday geologist who was nevertheless prominent enough to become the director of the Geological Survey of England, as the title page of the 1891 edition proudly announced.

Both translators of $T A D$ added material to the French original, especially material relating to British geology and to the work of British geologists. WSO remarked upon these additions in his "envoi", making it clear that his motivation was just as much a matter of national pride as of empirical completeness: "It has been considered desirable ... to enlarge upon the views of British geologists, to whom the French work scarcely does justice, considering the extent to which the science is indebted to them for its elucidation - I may almost say for its existence" (WSO 1865:vi). ${ }^{10}$ It is interesting to note that this sentence was maintained in almost unchanged form in all subsequent English editions but, in Bristow's version, some further remarks were added specifying Figuier's exclusive responsibility for the speculative content of the book (Bristow 1872:iii-iv):

Many points which are more or less inferential and therefore matters of individual opinion, and especially those on which M. Figuier bases his speculations, have been left in their original form, in preference to making modifications which would wholly change the character of the book. In a work whose purpose is to give the general reader a summarised account of the results at which science has arrived, and of the method of reasoning regarding the facts on which these generalisations rest, it would be out of place, as well as ineffective, to obscure general statements with those limitations which caution imposes on the scientific investigator.

This attitude is not uncommon in scientific translation; it derives from the particular status of the scientific text, which is routinely subjected to updating revisions by the author, and is therefore by nature less stable than most literary texts. The empirical ideal means that what is valued in a scientific text is its objective accuracy, not its textual authenticity. It is therefore not surprising that translators of scientific texts have generally felt less tied down by the originals than their literary colleagues. While the translator of a novel may be concerned only to produce as authentic a reading experience as possible - one that is as close to the spirit of the original as possible, however that 'spirit' is construed - the scientific translator can justify taking liberties with the source text by invoking a need for updating or for relocation within a distinct national tradition. At any rate, this was how WSO justified his 'anglicizing'

\footnotetext{
${ }^{10}$ WSO also dedicated his translation to the British geologist Roderick Murchison, at first sight a surprising choice given that Murchison was not an obvious sympathizer with Figuier's anti-evolutionary message. WSO himself was clearly aware of the oddity, and defended his choice by explaining in his preface that he did not take the dedication to signify any particular theoretical affinity between the British geologist and the French popularizer.
} 
additions to $T A D$, and he obviously felt it to be a perfectly legitimate practice. But it was Bristow who would later add the comment, already cited, that ring-fences Figuier's views as belonging to him alone, and even broadly hinting that they were not empirically justifiable. Bristow thus expresses an interesting mix of attitudes; on the one hand, there is the bank of empirical facts, to which the translator can add freely; on the other hand, there is the argument derived from the facts which the translator sets apart as the exclusive property of the author. However, the claim is blatantly disingenuous since the English translators did not leave the speculative content untouched, but made considerable efforts to 'correct' what they saw as problematic in the Frenchman's outlook. Bristow's ring-fencing statement was plainly a way of registering his scepticism as to the credibility of the author's ideas and, paradoxically enough, of justifying the changes that had been made.

WSO's anglicization of the French text was radical from the outset. The tenor of the translation is set in his rendering of the passage from the preface that sets out the general purpose of the book. Figuier's original version, which describes the project in the terms of studiedly sober empiricism, has already been cited. The equivalent passage in WSO's version is altogether more flamboyant, with the translator contriving to introduce quotations of both Genesis and Alfred Tennyson into this important statement (Figuier, trans.WSO, 1865:i.):

[The book's] object is to give a History of the progressive steps by which the earth has reached its present state, from that condition of chaos "when it was without form and void, and darkness covered the face of the waters," tracing the various convulsions and transformations through which it has passed, until in the words of the poet, it may be said -

Where rolls the deep, there grew the tree;

Oh earth, what changes hast thou seen!

There, where the long street roars, hath been

The silence of the central sea. ${ }^{11}$

Any readers who feared the dangers of unprotected exposure to Gallic scientific culture and its characteristically heathenish materialism must have felt greatly reassured by this opening!

Another highly visible change made by WSO was the suppression of the stratigraphical frontispiece that had helped Figuier's French readers understand and visualize the chronological structure of his account, and its replacement by the Riou scene depicting "the appearance of Man". The scene is strongly evocative of the familiar Edenic tradition, a distinctly modern pastoral scene inhabited by modern animals and a pair of equally modern humans whose only recognizable sign of 'antiquity' was their nakedness. This scene was changed by Figuier in the fifth French edition of 1865, when palaeontological evidence forced him to concede that the first Europeans had cohabited with species now extinct. He had Riou draw a new scene that abandoned the Edenic tradition in favour of a more naturalistic 'prehistoric' style. The men were still anatomically modern - unlike Boitard's - but they were now recognizably 'primitive' in that they wore skins and wielded clubs to protect themselves and their families from marauding hyenas and mammoths. The first English translation predated this change, so the new scene was not available for WSO; nevertheless, his decision to use the Edenic image to replace the stratigraphical diagram as frontispiece says a great deal about his repackaging of the text in such a way as to play down its empirical stance and to play up its compatibility with pious conventions.

\footnotetext{
${ }^{11}$ Parts of the verse passage are slightly misquoted. In the published version of the poem, the first line reads "There rolls the deep where grew the tree"; and in the fourth line "stillness" appears in the place of "silence" (Tennyson 1973:81-82).
} 
The Edenic scene displaced by WSO did not appear in its chronological place in the main body of the text. In Bristow's subsequent editions, the case was more complex. Although these editions appeared after Figuier had made his change, the eliminated scene continued to be used by Bristow as a frontispiece, while the new scene was now also used in the text. This dual representation of the same moment in two quite different modes is manifestly incoherent, but the contradiction does not seem to have bothered Bristow. In fact, it suited him to have it both ways: to let the naturalistic representation take its place in the material chronology even while the Edenic representation continued to diffuse its pious airs upon the work as a whole (Figure 2).

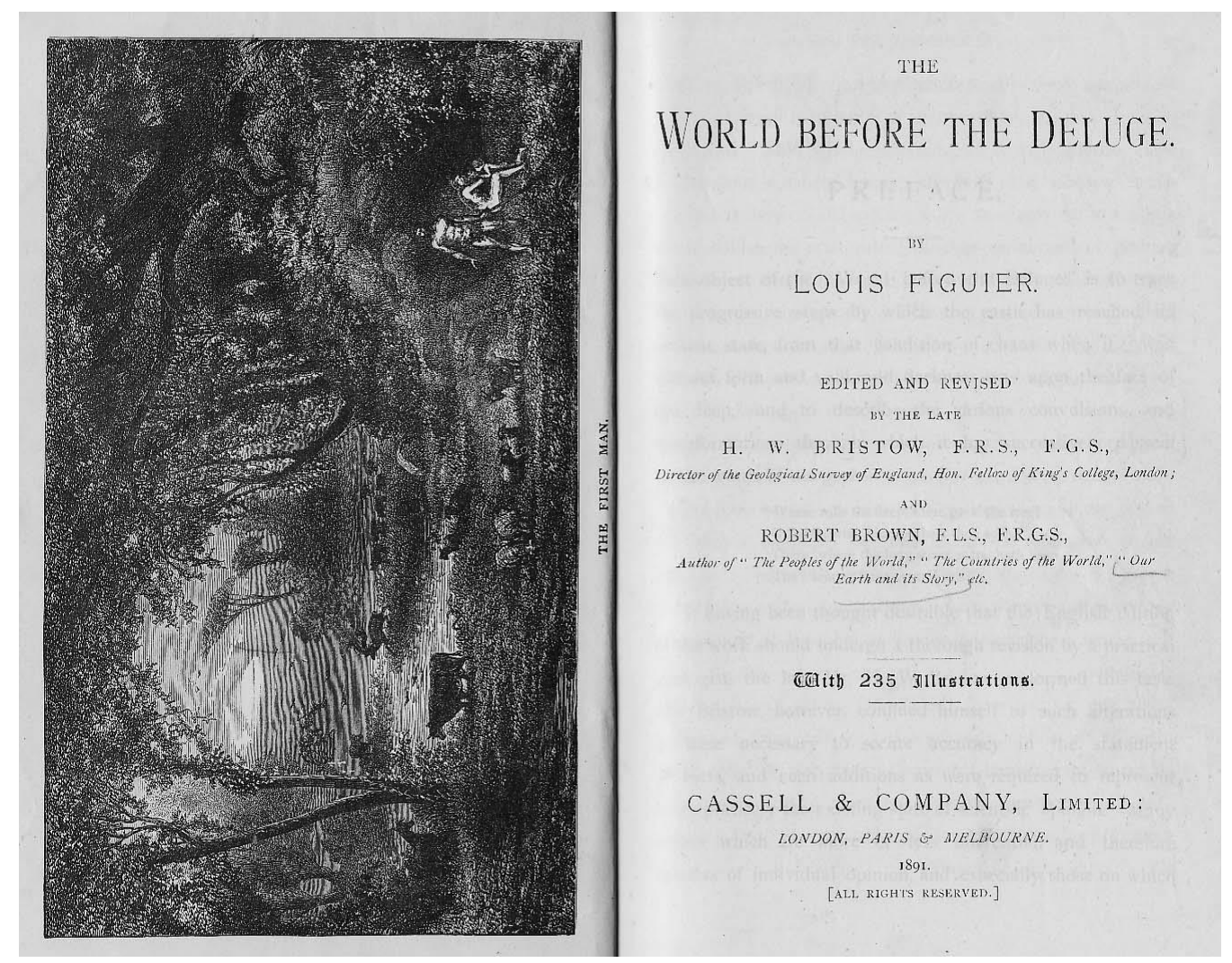

Figure 2. The title-page spread of the final English edition of 1891

A similarly radical and visible change was made in the choice of title for the work, in which la terre was rendered as the world. All the English editions maintained this choice, despite the fact that the earth would have been a more accurate translation. The difference is conceptually significant. The earth refers only to the material entity: the planet itself. The world, by contrast, has a much more diffuse meaning, and is often used as a synonym for the universe or the cosmos: a term that suggests 'the totality of all that exists'. In addition, that totality need not be restricted to material presences, but might include ideal or spiritual entities too. Where Figuier's title suggested the material history of a material entity, the title chosen by the English translators suggested the history of a closed system of the sort that might very well have been designed by a higher power. Their choice of terminology thus introduced just the sort of blurring of material process and transcendental-design dynamics that the French author's empirical stance had prompted him to seek to avoid.

When we turn to the detailed treatment of Figuier's text, we find that the manipulations of the translators tend in two general directions. First, there is a tendency to reduce the attribution of divine agency in the operation of mechanical processes. Secondly, there is a 
tendency to enhance the role of divine agency whenever the overall dynamics of the history of Life, or the specific creation of man are concerned. At first sight, these two tendencies appear contradictory. But once we have seen some examples of their operation, it will be clear that they were part of a coherent repackaging strategy that tailored WBD to the attitudes, expectations and values of a British readership.

\subsection{Effacing the Divine}

Some passages aim to reduce the divine presence in the rare moments when an attempt was made to describe the mechanics of the creative process. Such a moment occurs in a passage added in the third edition, where Figuier was describing the first origins of Life in the sea (Figuier 1864a:54):

C'est dans les eaux que la vie a commencé à s'éclore. Il ne faut pas oublier, en effet, qu'aux premiers temps de notre globe les eaux couvraient la plus grande partie de sa surface. C'est dans ce milieu que s'est accompli le mystère divin de la première apparition de la vie. Quand les eaux furent assez refroidies pour permettre l'existence des êtres organisés, la création s'exerça, et elle s'exerça avec une puissance extrême, car elle se manifesta par l'apparition d'espèces nombreuses et très-différentes. ${ }^{12}$

In WSO's translation of this passage, the implication of divine intervention in the creative moment is toned down (Figuier, trans. WSO, 1865:86):

We have stated that, in the first ages of the world, the waters covered a great part of its surface, and it is in the waters that we find the first appearance of life: in this medium was accomplished the first grand mystery of creation. When the waters were sufficiently cool to permit of organized existence, creation was developed, and exercised itself with great energy, for it manifests itself by the appearance of numerous and very different species of animals and plants.

What had been the divine mystery of creation becomes the grand mystery; furthermore, the active verb-form of la creation s'exerça becomes more discreet in the passive translation, creation was developed. In the later Bristow translation, the same tendency is even more strongly marked, all mention of mystery being dropped from the first sentence: "We have stated that, during the earlier ages of our globe, the waters covered a great part of its surface; and it is in them that we find the first appearance of life" (Figuier, trans. Bristow, 1872:100).

A similar passage occurs a little further on in the story, when Figuier describes the transition between the Silurian and the Devonian periods (Figuier 1864a:67-68):

Les continents déposés par les mers s'enrichirent, pendant la période dévonienne, de quelques espèces végétales et animales d'une organisation plus complexe que celles qui avaient apparu sur le globe primitif. On suivra sans doute avec intérêt, dans cet ouvrage, les progrès successifs que présente l'organisation des êtres à mesure que la terre avance en âge, et, pour ainsi dire, s'éloigne de son berceau. Le créateur semble s'appliquer sans cesse à produire des espèces vivantes de plus en plus achevées, car une espèce qui s'éteint est toujours remplacée par une autre perfectionnée. Nous avons vu pendant la période silurienne la vie éclore, et

\footnotetext{
12 Emphasis has been added here and in all subsequent citations where it appears.
} 
l'organisation débuter par des plantes d'un ordre tout à fait inférieur, par des Algues et des Varechs, par des Zoophytes, des Articulés, des Crustacés et Mollusques, qui disparaissent sans retour pendant la période suivante. Nous verrons, à mesure que notre globe vieillit, l'organisation se compliquer sans cesse. Les Vertébrés, représentés par de nombreux Poissons, succéderont aux Articulés, aux Crustacés et au Mollusques. Apparaîtront ensuite les Reptiles ; puis viendront les Mammifères et les Oiseaux ; jusqu'enfin Dieu fasse sortir de ses mains son suprême ouvrage, l'Homme, le roi de la terre, qui a pour signe et pour agent de sa supériorité, l'intelligence, cette flamme céleste, émanation de Dieu.

Once again, Figuier finds signs of the divine imprint in the empirically-traced patterns of species emergence; he even attempts to outline a general principle that might guide the divinely-supervised creative process: Le créateur semble s'appliquer sans cesse à produire des espèces vivantes de plus en plus achevées, car une espèce qui s'éteint est toujours remplacée par une autre perfectionnée. ${ }^{13}$ It is interesting to note that Figuier cut the final part of this sentence from the fourth edition (1864b), so that it ended at achevées. Ironically enough, he might have realized - belatedly - that the suggestion of species being 'replaced' by other more highly 'perfected' species gave far too much ground to the evolutionists. The potential confusion shows just how close the grand narratives of the two opposing 'schools of thought' really were. In the WSO translation, the whole of the passage in italics is simply cut out (Figuier, trans. Bristow, 1872 \&1891:120):

The rocks deposited during the Devonian period exhibit some species of animals and plants of a much more complex organisation than those which had previously made their appearance. We have seen, during the Silurian epoch, organisms appearing of very simple type; namely zoophytes, articulated and molluscous animals, with algae and lycopods, among plants. We shall see, as the globe grows older, that organization becomes more complex. Vertebrated animals, represented by numerous Fishes, succeed Zoophytes, Trilobites, and Molluscs. Soon afterwards Reptiles appear, then Birds and Mammals; until the time comes when man, His supreme and last work, issues from the hands of the Creator, to be king of all the earth - man, who has for the sign of his superiority, intelligence - that celestial gift, the emanation of God.

This excision was maintained by Bristow in all editions to 1891. On the other hand, the material at the end of the cited passage that explicitly invokes divine intervention in the creation of Man was duly included by WSO and maintained by Bristow. Once again, we see the English translators being coy about equating material process and divine intervention but not coy at all about giving man a special place in the story of natural creation.

\subsection{Enhancing the Divine}

The translators effaced Figuier's invocations of divine intervention only in those settings which sought signs of providential guidance in the actual material processes of creation, as seen in the examples just discussed. On the other hand, they tended to enhance Figuier's

\footnotetext{
${ }^{13}$ My own translation of this sentence: "The Creator seems ceaselessly to apply Himself to the production of ever-improved forms of life, and we see that a species that dies out is always replaced by another more highly perfected."
} 
divine references when they entailed only a general reference to the guidedness or goodness of the overall scheme of things, or indeed, as we have seen, when the creation of man was involved.

In the following passage, Figuier defends the Megatherium, a giant ground sloth of the quaternary, against Buffon's view that this animal had "received the most vicious organisation"; that it was "a being to which nature has forbid all enjoyment: which has only been created for hardships and misery". Against these views, Figuier insists on the Megatherium's adaptedness (Figuier 1863a:276):

De même, si l'on considère le mégathérium comme ayant été créé pour fouiller la terre et se nourrir des racines des arbres et des arbustes, chacun des organes de sa lourde charpente paraîtra parfaitement approprié à son genre de vie et bien adapté à l'objet spécial qui lui a été assigné par la nature.

WSO translated this passage in a straightforward manner until he reached the final phrase, which he gratuitously transformed to make the Megatherium "well adapted to the special purpose which was assigned to it by the Creator" (Figuier, trans.WSO, 1865:358). The change was maintained by Bristow (Figuier, trans. WSO, 1865:358; Figuier, trans. Bristow, $1872 \& 1891: 405)$ :

In the same manner, if we consider that the Megatherium was created to burrow in the earth and feed upon the roots of trees and shrubs, every organ of its heavy frame would appear to be perfectly appropriate to its kind of life, and well adapted to the special purpose which has been assigned to it by the Creator.

The same tendency is much in view in Figuier's section dealing with the creation of Man. For example, the French author broaches the issue of monogenetic as against polygenetic hypotheses in impeccably empirical terms: "On a écrit des volumes sur la question de l'unité du genre humain, c'est-à-dire pour se décider s'il y a eu plusieurs centres de création de l'homme, ou si la souche de notre espèce est unique" (Figuier 1863a:361). However, WSO decided to sacralize the moment by bringing in a reference to Adam: "Volumes have been written upon the question of the unity of the human race; that is, whether there were many centres of the creation of man, or if the parent of our race was the Adam of Scripture" (Figuier, trans. WSO, 1865:419). Bristow slightly revises the wording to make the monogenesis hypothesis clearer, but maintains the Biblical slant. In his version, the second option becomes: "or whether our race is derived solely from the Adam of Scripture" (Figuier, trans. Bristow, 1872:469).

Even more telling is the handling of the Flood. This was a somewhat delicate passage for Figuier. It was important for him that this central Biblical event retain a place in the scientific understanding of the geological past, but only empirical considerations would give him a legitimate basis for including the deluge as an event in his historical account. The fact that the deluge was mentioned in the book's title is a measure of just how important the inclusion was to the author. In the passage in question, Figuier argued that the Flood - or rather the "Asiatic flood" which he distinguished from an earlier "European flood" preceding the creation of Man - was a real event, attested by geological evidence (Figuier 1863a:370-71) :

Rien n'empêche de voir dans le déluge asiatique; conformément au texte de la Génèse, un moyen dont Dieu se servit pour châtier et punir la race humaine, alors au début de son existence, et qui s'écartait des voies qu'il lui avait tracées. Ce qui paraît établi, c'est la naissance du genre humain dans les contrées qui partent du 
Caucase... Le déluge biblique est donc réel. Plusieurs peuples ont, d'ailleurs, conservé la tradition. ... Ainsi, nous le répétons, le déluge biblique est réel; seulement, il fut local, comme tous les phénomènes de ce genre, et fut la conséquence du soulèvement des montagnes de l'Asie occidentale.

In the sixth French edition, Figuier cut out the first sentence of this passage in its entirety. The most likely explanation is that the reference to the Flood as God's way of punishing man for his sins did not adequately conform to the author's empirical ideals. Throughout the publication history of $T A D$, Figuier never ceased to work towards the realization of these methodological ideals by making such deletions as this. By contrast, the English translations betrayed a rather different set of preoccupations (Figuier, trans. WSO, 1865:431-32):

Nothing occurs, therefore, in the description given by Moses, to hinder us from seeing in the Asiatic deluge a means adopted by God to punish the human race still in its infancy. It seems to establish the countries lying at the foot of the Caucasus as the cradle of the human race; ... [Sentence cut.] Of this deluge many races besides the Jews have preserved the tradition. ... Thus the Biblical deluge (Plate XXXIII) is confirmed in many respects; but it was local, like all phenomena of the kind, and was the result of the upheaval of the mountains of western Asia.

Suprisingly, WSO tones down the 'wrath of God' tendency of Figuier's opening sentence, but the reference to divine design is nevertheless maintained, and made even more emphatic by the reference to Moses as the author of the text. More importantly, and more in keeping with the patterns already established, WSO also eliminates Figuier's key claim as to the reality of the Flood. The claim was important enough to the French author for him to repeat it twice in this brief passage; nevertheless, WSO simply cuts out the sentence in which the claim is first made, and tones down the second so that "Ainsi, nous le répétons, le déluge biblique est reel" becomes "Thus the Biblical deluge is confirmed in many respects". All of the Bristow editions from 1872 to 1891, postdating Figuier's removal of the first sentence of this passage, modify the WSO translation's light treatment of this passage to bring it into closer conformity with the earlier, excised French version (Figuier, trans. Bristow and Brown, 1891:482):

Nothing occurs, therefore, in the description given by Moses, to hinder us from seeing in the Asiatic deluge a means made use of by God to chastise and punish the human race, then in the infancy of its existence, and which had strayed from the path which He had marked out for it.

The rest of the passage in Bristow continues as it had done in WSO.

The passage relating to the first appearance of Man is also worth mentioning. In his early editions, Figuier had allowed this moment to take on a certain piety of tone reminiscent of that which we have already seen in relation to the Flood (Figuier 1863a:360-61):

Pour annoncer dignement le nouvel habitant qui va remplir le globe de sa présence, celui qui vient admirer, comprendre, dominer et asservir la création, il ne faut rien moins que la langue antique et vénérée de Moïse. ... Ecoutons en conséquence les paroles de Moïse, le prophète, le législateur inspiré: « L’Eternel dit ensuite: « Faisons l'homme à notre image et à notre ressemblance .... ».

Just as with the material on the Flood, this passage was removed by the author in the sixth edition of 1872, no doubt for the same reasons. But it was the sort of thing that the English 
translators liked, and the equivalent passage was retained in all editions to 1891 (Figuier, trans. WSO, 1865:419):

In order to usher in worthily the new inhabitant who comes to fill the earth with his presence - who brings with him intelligence to comprehend, to admire, to subdue, and to rule the creation (Pl. XXXII), we require nothing less than the ancient and venerated language of Moses ... The words of the inspired legislator are as follows: "And God said, Let us make man in our image, after our likeness ...".

It is interesting that the translation adds a direct reference to the accompanying scene, $\mathrm{Pl}$. XXXII, the very scene that Figuier had changed in the fifth French edition of 1865, as already mentioned. The change from the Edenic to the more naturalistic version of this scene must have played a part in Figuier's decision to excise the reference to Genesis in the following edition of 1872, even though his text contained no specific signposting towards the illustration. But the English translators showed no such compunction. WSO's 1865 translation, predating Figuier's replacement of the scene, had removed the illustration from the main part of the text in order to promote it to the place of frontispiece. Bizarrely enough, we therefore find in the text a reference to "Pl. XXXII", but no plate XXXII in sight! In the Bristow editions from 1872 to 1891, the new Riou illustration was inserted in its proper place in the text, while the former illustration continued as frontispiece; but despite this modernization, Bristow ignored Figuier's parallel excision of the Biblical reference, and maintained the old WSO translation almost verbatim (Figuier, trans. Bristow and Brown, 1891:469):

In order worthily to introduce the new inhabitant who comes to fill the earth with his presence - who brings with him intelligence to comprehend, to admire, to subdue, and to rule the creation (Pl. XXXII), we require nothing more than the grand and simple language of Moses ... Let us listen to the words of the inspired writer: "And God said, Let us make man in our image, after our likeness...".

On the page facing this text, Pl. XXXII has now reappeared; only it is no longer the Edenic scene that fitted so easily with the Genesis-inspired text, but Riou's new scene incongruously featuring cavemen, hyenas and mammoths! As far as the text is concerned, Bristow's modifications are minor, but in one case significant. WSO's "we require nothing less than the ancient and venerated language of Moses" becomes "we require nothing more than the grand and simple language of Moses"; the change from "nothing less than" to "nothing more than" is a new departure from Figuier's original "rien moins que". Bristow was thus not only reestablishing text that had been excised by the author, but also revising the existing translation in a way that made it less faithful. . Perhaps the intention was to normalize the status of "the language of Moses", so that the evocation of Genesis alongside the latest findings of natural science might seem a self-evident rather than an extraordinary discursive stance.

\section{A plot replotted}

The English translators took significant liberties with Figuier's text. The 'History of Life' traced in WBD was subtly but significantly altered, with the translators tending to revise the place attributed to divine providence by the French author. They diminished the divine presence in any passages where Figuier associated it with the material processes of chronological change, but enhanced it whenever the text touched on the the overall dynamics 
of the history of Life, or on the special place of Man in the natural creation. The English translators thus tended to emphasize the very passages that Figuier himself had preferred to eliminate in the later French editions.

The modifications were relatively minor in material terms, but their conceptual impact was disproportionately significant. They were sufficient to give the plot a different slant, which is important given that it is precisely the plot dynamic that carries all the ideological content of an empirical History of Life. Working in a markedly secularized context, Figuier was attempting to defend his religious values in the only practical way open to him as a popularizer of science in France, via empiricism. TAD was intended as an empirical defence of religion. It told the studiedly empirical story of the development of Life, and contrived to present the plot dynamics of that story as incompatible with the evolutionary dynamics of material emergence. The only hypothesis compatible with the facts - characterized everywhere by hiatuses in the chronological continuum - was that the overall plot had been shaped by a transcendent author. The claim was made in purely naturalistic terms; Genesis was occasionally cited, as we have seen, but only to argue that key events such as the deluge were substantially borne out by the geological evidence. Figuier attempted no direct argument involving moral values, nor did he invoke any moral absolutes that ought to transcend or precede empirical method. To have done so would have been to step out of the space reserved for scientific discourse in France.

The popularizing mission, whether undertaken in France or elsewhere, always required the capacity to reassure the audience that science was not harmful, that it was in fact good for them. But in the French context, popularizers like Figuier were wary of offering such reassurance in directly moral terms; they had to seek it instead in the findings of the scientific disciplines. Science is safe, Figuier effectively said, because its results are compatible with the core religious teachings. What he could not do was to cite moral considerations as a reason for approving of a scientific theory. This does not imply that he had no moral agenda, simply that he had to be careful not to publicize it as such.

The British context was markedly different. Here too it was necessary to reassure neophytes as to the safeness of science. But in a society that was much less marked by the politics of secularism, a popularizer was not going to get far by sidelining moral questions. From the point of view of the British non-scientific establishment, the connections between science, materialism and Jacobinism were all too obvious; and any attempt to defend science on purely empirical terms would therefore have been accused of just the sort of immoralism that belonged on the other side of the Channel. The values of the British middle-classes - as represented for example in the novels of Dickens - tended to make moral issues supreme, and to require science to find its place under that umbrella. The actual practice of scientific disciplines by definition had to be undertaken in an empirical spirit; nevertheless, the legitimacy of Science as a whole depended not only on whether or not its findings were materially true, but also on whether or not its findings would reinforce our moral being, as individuals and as a society. It was to values of this sort that popularizers of science had to appeal in the British context if they were to reassure their readership as to the safeness of science.

In the context of nineteenth-century Britain, WSO and Bristow were able to free themselves from the self-imposed empirical restraints that had characterized Figuier's work. The liberation was in fact not only possible but even desirable. The generalist British reader might not be adequately reassured by a strictly empirical account; he or she would want more direct assurances of the moral basis of the scientific attitude. Readers wanted to see God's goodness vindicated not only by the results of science, but also by the way its practitioners looked at and talked about the world they studied. 
Seen this way, the manipulations of WSO and Bristow make perfect sense. It seems likely that the translators reduced Figuier's invocation of divine involvement in the material processes of chronological change because they wanted no part in a mode of argument in which theological considerations had to be disguised as part of an empirical argument. They may have been uncomfortable with any such blurring of material process and divine supervision, preferring instead to maintain a clear distinction between the former domain, which was appropriately addressed in empirical terms, and the latter domain, which needed a distinct transcendent framing.

Meanwhile, the translators' opposite strategy of enhancing the divine role in passages dealing with the overall plot-dynamic of the history of Life or the creation of Man worked towards the same end. While Figuier had had to avoid empirically unjustifiable assertions, and made consistent efforts over time to eliminate any assertions based exclusively on biblical authority, the English translators not only held on to all such material, but even exaggerated it. There was no harm for them in bringing in as many passing references as possible to Adam as the first man or to the Flood as divine punishment for sinners, nor even in hinting that the Megatherium's designer was God himself; none of these references would prompt the target audience to reject the book as 'unscientific', since they all relate to the general orientation of creation, not to its mechanical processes. Instead, such interventions were useful because they signalled in a highly visible manner the moral conformity of those responsible for producing this scientific knowledge and thus nipped in the bud any instinctual hostility to their discipline.

$W B D$ was not intended as a faithful translation of $T A D$, but it was the sort of translation that had a chance of working in the British context. In other words, it would, like the French original, provide the basis upon which a youthful middle-class audience might familiarize itself with the science of palaeontology. But the formal differences discussed here also had an impact on the work's ideological orientation. The freedoms taken by the translators in investing the account with numerous references to divine stewardship of the overall plot of the history of Life were important not only for their capacity to reassure a conservative readership. They also had the effect of effacing the dual plot structure that Figuier had deployed as the argumentative basis for his empirical defence of religion, and of replacing it with a simpler unified narrative in which God played a less concrete though equally significant role. This replacement narrative also treated the story of Life empirically, but it made of God a constant background presence. Material process and divine logic were no longer different aspects of the scientific issue, but merely 'lower' and 'higher' ways into the same story. With this general outlook, Figuier's dual plot structure was easily reunited into a single strand, in which the general progressiveness of nature is foregrounded and the positive orientation of that dynamic effectively guaranteed by God's external but all-pervasive supervision.

WBD thus presented a straightforward world characterized by a gratifyingly linear and progressive history. Its story was one of gradual material improvement under the guidance of a higher moral power, a plot dynamic perfectly compatible with a certain conception of the evolutionary process. The modern understanding of evolution is quite different, of course, but many nineteenth-century promoters of Darwinism looked no further than an outlook of this kind. If Figuier's book started as a religiously motivated empirical attack on evolutionary theory in France, then, in its English translation it effectively shifted camps to become an apology for just the opposite view. In managing this extraordinary shift, the translators showed just how powerful a weapon pious progressivism might be for those who sought to establish the respectability of evolutionary thought in Victorian Britain. 
Université de Nancy 2, 3, place Godefroi de Bouillon, BP 3317, 54015 Nancy Cedex, France. Richard.Somerset@univ-nancy2.fr

\section{References}

Boitard, Pierre (1861) Etudes antédiluviennes, Paris avant les hommes, l'homme fossile, etc. (Antediluvial Studies, Paris Before Mankind, Fossil Man, etc.), Paris: Passard.

Brisset, Annie (2002) 'Clémence Royer, ou Darwin en colère' (Clemence Royer, or Darwin in Anger), in Jean Delisle (ed.) Portraits de traductrices (Portraits of Women Translators), Ottowa: Presses de l'Université d'Ottawa, 173-203.

Bristow, Henry (1872) 'Preface', in Louis Figuier, The World Before the Deluge, London: Cassell, Petter \& Galpin.

Figuier, Louis (1863a, 1863b, 1864a, 1864b, 1866, 1872, 1877, 1879, 1883) La Terre avant le déluge, Paris : Hachette.

----- (1865) The World Before the Deluge, trans. WSO, London: Chapman \& Hall. (1867, 1869) The World Before the Deluge, trans. Henry Bristow, London: Chapman \& Hall.

----- (1872) The World Before the Deluge, trans. Henry Bristow, London: Cassell, Petter \& Galpin.

(1891) The World Before the Deluge, trans. Henry Bristow and Robert Brown, London: Cassell \& Company.

Miles, Sara Joan (1989) 'Clémence Royer et De l'origine des espèces: Traductrice ou traîtresse?' (Clemence Royer and The Origin of Species: Translator or Traitor?), Revue de Synthèse 110: 61-83.

Rudwick, Martin J.S. (1992) Scenes from Deep Time: Early Pictorial Representations of the Prehistoric World, Chicago: University of Chicago Press.

Tennyson, Alfred (1973) In Memoriam, edited by Robert H. Ross, New York \& London: W.W. Norton \& Co.

WSO (1865) 'Preface', in Louis Figuier, The World Before the Deluge, London: Chapman \& Hall. 